\title{
POMEN VZDRŽEVANJA DINAMIČNEGA RAVNOVESJA ZA SONARAVNI RAZVOJ
}

\author{
Metka Špes \\ Oddelek za geografijo Filozofske fakultete v Ljubljani, Aškerčeva 2, \\ SI - 1000 Ljubljana, Slovenija \\ e-mail: metka.spes@ff.uni-lj.si
}

Izvirni znanstveni prispevek

COBISS 1.01

\section{Izvleček}

Sonaravni razvoj pomeni predvsem iskanje in vzdrževanje ravnovesja med materialnim blagostanjem, socialno varnostjo in zdravim okoljem. Naravni ekosistemi so v evoluciji dokazali, da imajo regulatorje svojega delovanja, ki jih vzdržujejo v dinamičnem ravnovesju in jim s tem zagotavljajo preživetje tudi ob spremembah. V prispevku so predstavljeni nekateri od teh ekosistemskih mehanizmom ravnovesja, ki lahko služijo tudi kot vzorci človekovega delovanja in posegov v okolje.

Ključne besede: ekosistemska stabilnost, dinamično ravnovesje, mehanizmi ravnovesja, sonaravnost.

\section{THE IMPORTANCE OF MAINTAINING THE DYNAMIC EQUILIBRIUM FOR SUSTAINABLE DEVELOPMENT}

\begin{abstract}
Sustainable development means principally the search for and the maintaining of the equilibrium between material welfare, social security and healthy environment. Natural ecosystems have proved throughout the evolution that inherent to them are regulators of their functioning that maintain their dynamic balance and, resultantly, ensure their survival even in the case of changes. The paper presents some of these ecosystem balancing mechanisms, which can also serve as examples to human activity and interventions into the environment.
\end{abstract}

Key words: ecosystem stability, dynamic equilibrium, balancing mechanisms, sustainability. 


\section{SONARAVNOST KOT EVOLUCIJSKI PROCES}

Človek je z razvojem znanja in tehnologije sposoben posegati v vse ekosisteme na našem planetu in jih tudi spreminjati. Za kvaliteto našega življenja in tudi preživetja pa je pomembno, da se s svojim delovanjem čim bolj približamo naravnim zakonitosti, da s posegi ne rušimo naravnega ravnovesja, da ne presegamo njihovega naravnega potenciala in, da $\mathrm{v}$ razvoj vključujemo sonaravna načela in cilje. Danes skoraj ni mogoče najti razvojnega dokumenta ali okoljevarstvenega razmišljanja, ki se ne bi sklicevalo na paradigmo sonaravnosti, a so njegove razlage ali implementacije $\mathrm{v}$ prakso različne in pogosto tudi neskladne $\mathrm{z}$ osnovno idejo sonaravnosti. Če se vrnemo k izvoru nastanka ideje sonaravnosti, k dokumentu Our Common Future (ali t.im. Brundtlandino poročilo), ki ga je leta 1987 pripravila Svetovna komisija za okoljski razvoj, najdemo najbolj nedvoumno razlago, da je to »proces sprememb, kjer je izkoriščanje naravnih virov, usmerjanje investicij, tehnološkega napredka in institucionalnih sprememb skladno tako s sedanjimi kot prihodnjimi potrebami«. Pomembno je spoznanje, da doseganje sonaravnosti ni končni cilj, ampak je uravnotežen in prilagodljiv evolucijski proces iskanja ravnovesja med materialnim blagostanjem, socialno varnostjo in zdravim okoljem.

Načrtovanje sonaravnega razvoja torej ne pomeni le varovanje okolja, naravnih virov in značilnosti pokrajine, temveč okolju (in prostoru) prilagojeno razmeščanje naselij, dejavnosti in infrastrukture, rabe zemljišč in drugih okoljskih virov. Želeni sonaravni razvoj v prostoru opredeljujemo kot postopno približevanje tisti pokrajini, ki v danih razmerah izkazuje kolikor je mogoče uravnoteženo stanje $\mathrm{z}$ vidika funkcionalnih, ekoloških in kulturnih vrednot. Temeljni cilj je kvalitetna in vitalna pokrajina, ki bo funkcionalno, ekološko in oblikovno uravnotežena. Pri tem zagotavljanje funkcionalne pokrajine pomeni tak razvoj, ki hkrati z gospodarsko učinkovitostjo ohranja naravne vire in druge naravne in kulturne vrednote prostora. Ekološko uravnotežena pokrajina je tista, ki ob gospodarski učinkovitosti v čim večji meri ohranja naravne prvine in naravne procese (Plut, 2002).

Usmerjanje v sonaravnost bi moralo imeti globalne dimenzije, obstaja pa tesna povezanost med lokalnimi in globalnimi procesi. Regije so namreč odprti sistemi z medsebojnimi sovplivi. Pri odprtih sistemih pa se preko meja lahko prenaša tudi »nesonaravnost« (Nijkamp\&Perrels, 1994).

\section{VZDRŽEVANJE EKOSISTEMSKEGA RAVNOVESJA}

Koncept sonaravnosti v bistvu izvira iz razumevanja ekosistemske dinamike, ki, ne glede na kratkoročne spremembe ali vplive, zagotavlja eksosistemom stabilnosti oziroma dinamično ravnovesje. Dopušča spremembe, človekove vplive oziroma razvoj, vendar le do meje, ko ni presežena nosilnosti okolja. »Sonaravnost« ni enota za preživetje, ampak pomeni nadaljevati kvalitetno in z naravo sladno življenje v spremenjenih razmerah« (Nijkamp \& Perrels,1994). Bistvo sonaravnega razvoja je v tem, da so ekosistemi sposobni prenesti kvalitetne spremembe, ki dolgoročno prinašajo socialni, gospodarski in tehnološki razvoj. Pri teh spremembah lahko kratkoročno posamezni deli sistema sicer zanihajo 


\section{v nesonaravnost, a dolgoročno se morajo vedno uravnotežiti z naravnim potencialom oziroma nosilnostjo okolja.}

Ko v sistem vnesemo določeno spremembo, lahko ta povzroči še niz drugih sprememb, vendar večina ekosistemov, ki jih človek še ni povsem preoblikoval, nenehno teži k vzpostavitvi ravnovesja (Slika 1). Naravni ekosistemi, ki imajo več sestavin - so bolj pestri, se tem spremembam lažje prilagodijo in hitreje vzpostavijo novo ravnovesje. Če tega ni ali pa je porušeno in je izgubljena ekosistemska stabilnost, pride do degradacije, izgube biotske pestrosti, nezdravega in nekvalitetnega življenjskega okolja itd.

Slika 1: Vzdrževanje dinamičnega ravnovesja za zagotavljanje sonaravnosti

Figure 1: Maintaining the dynamic equilibrium for sustainability

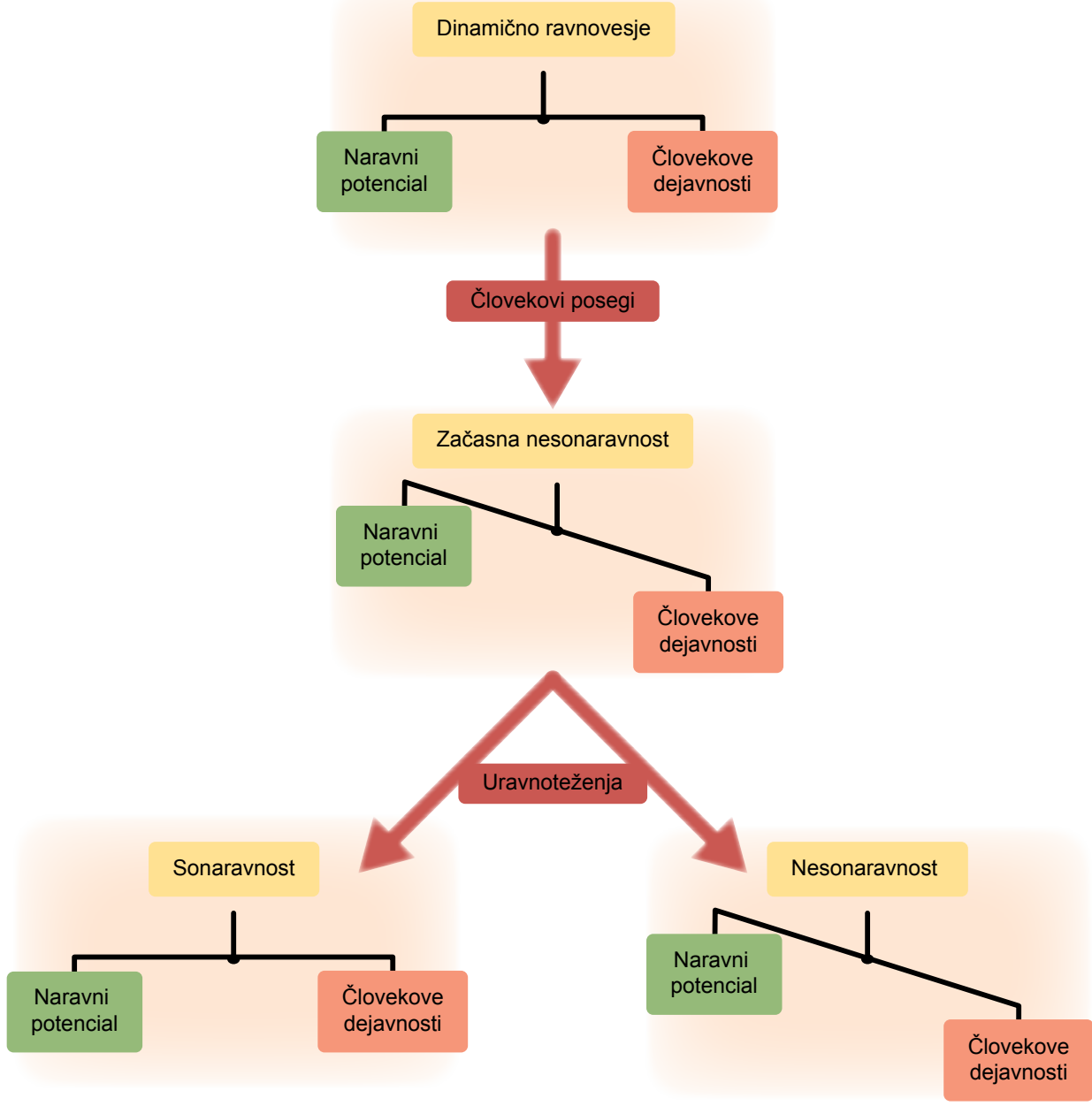


Poznamo več tipov ravnovesij, a z vidika delovanja ekosistemov sta najpomembnejša stabilno in dinamično ravnovesje:

Do stabilnega ravnovesja pride v primeru popolne uravnoteženosti med energetskimi in materialnimi vnosi in iznosi in takšno razmerje se konstantno vzdržuje skozi daljše časovno obdobje. Tovrstnih ekosistemov je na našem planetu zelo malo in so prostorsko omejeni. Vzdržujejo ga lahko le naravni oziroma antropogeno povsem nespremenjeni ekosistemi, ki imajo skozi daljši čas tudi nespremenjene klimatske razmere (nespremenjeni energetski vnosi). Zaradi odprtosti vseh ekosistemov na Zemlji, lahko pride do rahlo spremenjenih količin ali smeri energetskih vnosov, vendar se v naravnem ekosistemu takoj sproži povratna zanka, ki ustvari novo notranjo razporeditev energije in materije in ponovno se vzpostavi stabilno ravnovesje.

Pogosteje pa med naravnimi, pretežno naravnimi ali delno antropogeno preoblikovanimi prevladujejo ekosistemi, ki imajo sposobnost, da vzdržuje dinamično ravnovesje. Stabilnost oziroma odpornost omogoča ekosistemom, da se ob nenehnih kratkotrajnih zunanjih vplivih (šokih) sami obnavljajo, ker težijo k dolgoročni stabilnosti in imajo sposobnost, da se na zunanje vplive adaptirajo, jih absorbirajo oziroma jih nevtralizirajo in ustvarijo novo ravnovesje (Park, 1997). Ekosistemsko sposobnost prilagajanja novim razmeram povečuje njihova raznovrstnost in s tem tudi pestrejša paleta možnosti novih energetskih in snovnih povezav (pomen biotske pestrosti!). Dinamično ravnovesje se lahko poruši ob človekovih posegih, ki so premočni ali, ko gre za hitre spremembe oziroma vplive aktivnosti, ki součinkujejo ali se sinergijsko dopolnjujejo ter spreminjajo snovno-energetski pretok skozi ekosistem. Tako porušijo tudi sistemsko stabilnost in prinašajo nepričakovane ter nepredvidljive učinke, ki so v nasprotju s sonaravnim razvojem.

Zahteven strokovni izziv pa je odgovor na vprašanje: kje je prag oziroma kritična točka, ko ekosistem s svojimi mehanizmi ne bo več zmožen vzpostaviti dinamičnega ravnovesja? Problem je še v tem, da se nekateri ekosistemi hitro odzovejo na spremembe, drugi pa z zamudo oziroma zamikom, nekateri s predhodnimi opozorili, drugi brez njih. Čas odziva oziroma časovni zamik je odvisen predvsem od raznovrstnosti in kompleksnosti ekosistema. Enostavnejši ekosistemi, z manjšim številom notranjih povezav in energetsko -snovnih pretokov med posameznimi členi, se na spremembe odzovejo hitreje, njihov prag vzdrževanja dinamičnega ravnovesja je nižji. Kompleksnejši in raznovrstni sistemi pa imajo sposobnost, da dalj časa vzdržujejo ravnovesje in, zaradi poznih opozoril, dopuščajo dolgotrajnejše posege brez škodljivih posledic. Zaradi zapletenosti prepoznavanja mnogovrstnih povezav med posameznimi sestavinami ekosistema je težje predvideti in napovedati, kdaj bo nastopil prag oziroma kritična točka, ko bodo vplivi sprožili negativne spremembe, ko bo presežena zmožnost vzdrževanja ravnovesja.

Preproste in predvidljive linearne povezave med sestavinami so značilne za manjše in enostavne ekosisteme, $\mathrm{z}$ velikostjo in raznovrstnostjo pa narašča število bolj nepredvidljivih in zapletenih nelinearnih povezav in tistih s časovnim zamikom.

Kljub sorazmerno dobremu poznavanju delovanja ekosistemov, razvoju tehnologije oziroma orodij, s katerimi jih spremljamo, smo še vedno soočeni s precejšnjo stopnjo nepredvidljivosti in nezmožnosti, da bi razumeli in poznali vse njihove sestavine, pretoke in ener- 
getske pretvorbe, predvsem pa njihove povezave v nekem časovnem obdobju. V tem gre iskati tudi razloge, ne pa opravičila, za številne napake pri človekovih posegih v okolje.

Park (1997) ugotavlja, da so glavni razlogi za negotovost in nepredvidljivost:

- ekosistemska kompleksnost in raznovrstnost, kjer so spremembe rezultat kompleksnih in številnih interakcij med sestavinami in so zato težje predvidljive;

- težko napovedljivi pragovi, ker lahko učinki nastopijo tudi nenadoma, brez opozorila;

- nelinearni odgovori na spremembe, kjer učinek ni neposredno odvisen od velikosti vzroka;

- neučinkovitost obstoječih modelov, ker so okoljske spremembe rezultat številnih interakcij med večjim številom elementov, obstoječi modeli pa znajo razložiti le soodvisnost omejenega števila sestavin;

- $\quad$ pomanjkanje informacij o preteklih spremembah in vplivih;

- obstoj neidentificiranih, nemerljivih in neupoštevanih dejavnikov;

- včasih je težko napovedati ali predvideti hitrost oziroma čas odziva na spremembe (npr. odgovor ekosistemov na globalno segrevanje ozračja).

Ključni problem pri načrtovanju človekovih posegov je tudi pomanjkanje celovitega pristopa. Tako se dogaja, da postane rešitev enega problema na določenem področju, vir novega problema na istem ali drugem. Bistvo holističnega pristopa, ki je ključen pri načrtovanju sonaravnega razvoja, je spoznanje, da so vsi elementi znotraj kompleksnega sistema med seboj povezani na različne načine.

\section{MEHANIZMI ZA VZDRŽEVANJE EKOSISTEMSKEGA RAVNOVESJA}

Sonaravni razvoj je torej permanentno iskanje in vzdrževanje dinamičnega ravnovesja med naravnim potencialom oziroma regeneracijskimi sposobnostmi okolja in človekovimi posegi, ki so v funkciji izboljšanja njegovih materialnih in socialnih potreb. Pri tem je pomembno, da poznamo in upoštevamo osnovne zakonitosti delovanja naravnih ekosistemov, ki so organizirani tako, da nenehno težijo k stabilnosti in vsaka sestavina opravlja več nalog hkrati. Postavlja se vprašanje, po katerih zakonitostih deluje narava tako racionalno, da je skozi daljše časovno obdobje zmožna ohranjati ravnovesje.

Vester (1991) opozarja, da so naravni ekosistemi skozi evolucijo dokazali, da imajo neke notranje regulatorje, ki jim zagotavljajo vzdrževanje dinamičnega ravnovesja in preživetje. Omenjeni avtor je vzore za razlago zakonitosti, po katerih delujejo naravni ekosistemi, poiskal v biokibernetiki. Beseda izhaja iz grške besede »krmar«-zakonitosti, ki krmarijo ekosisteme. Regulatorji ali ekosistemski mehanizmi so lahko tudi dobri vzorci za človekovo delovanje, ki teži k ohranjanju ravnovesja, kar je temelj sonaravnosti. V nadaljevanju je nekaj primerov, kako lahko vzorce ekosistemskih mehanizmov ravnovesja, Vester (1991) jih je definiral osem, iz naravnih ekosistemov prenesemo tudi v človekovo sonaravno delovanje. 
Med najpomembnejše regulatorje naravnih ekosistemov sodi zakonitost „neodvisnost funkcije od količinske rasti“. V naravi je ohranjanje ravnovesja nezdružljivo s stalno rastjo, ker je s tem ogroženo preživetje. Odvisnost od rasti je namreč nevarna in je ekosistemski nesmisel. Tudi sestavine, ki količinsko ne rastejo, lahko v ekosistemu kvalitetno opravljajo svojo funkcijo. Predvsem je pomembno spoznanje, da ni soodvisnosti med opravljanjem funkcije in stopnjo rasti, ker je rast je prehodna, časovno omejena.

$\mathrm{Z}$ vidika sonaravnosti je torej nesprejemljivo, da je gospodarska rast najpomembnejši kazalec uspešnosti neke družbe, ali tržišče edino merilo presoje. Lah (2004) opozarja, da ni razvitega gospodarstva brez proizvodnje, storitev in trženja, toda res je tudi, da se je v zadnjih desetletjih 20. stoletja gospodarska aktivnost globalna povečala za $150 \%$, narava pa v istem obdobju za tretjino skrčila in poslabšala. Ker je Slovenija v preteklosti svoj gospodarski razvoj dosegala tudi na škodo okolja, je pomembno, da je vsaj deklarativno v Nacionalnem programu varstva okolja zapisano, da bo do leta 2013 pričakovan gospodarski napredek (ne rast!!) in dvig blaginje naša država dosegala ob učinkoviti rabi naravnih virov, ohranjanju narave in ob dvigu kakovosti bivalnega okolja (MOP, 2005). V praksi pa žal, spremljamo le informacije o veliki gospodarski rasti, namesto o tem, kako gospodarska rast vpliva na socialno pravičnost in zmanjšano izčrpavanje naravnih virov in onesnaževanje okolja.

$\mathrm{V}$ naravnem ekosistemu ima vsaka njegova sestavina neko funkcijo, neodvisno od proizvoda. To jim omogoča veliko prilagodljivost in preživetje tudi ob spremembi. Zakonitost označujemo kot» neodvisnost funkcije od proizvoda « Sestavina, ki je v ekosistemu organizirana v skladu s svojo nalogo, ne glede na končni proizvod, se na spremembe hitreje in bolje prilagodi.

Z intenzifikacijo kmetijstva in težnjami po pridelavi večjih količin hrane, se je $\mathrm{v}$ zadnjih desetletjih močno povečal donos tudi v Sloveniji. S povečanimi energetskimi vnosi pa so se začeli množiti negativni okoljski učinki kmetovanja, predvsem v onesnaževanju voda (podtalnice) pa tudi prsti, $v$ škodljivih učinkih na rastlinah in živalih. Po priključitvi k EU se je jasno pokazalo, da naše konvencionalno kmetijstvo v novih razmerah ni konkurenčno in, da ga v bodoče na bomo mogli presojati le po prispevku k BDP-ji, količini pridelane hrane, ampak po njegovi vlogi pri ohranjanju kulturne pokrajine in biotske pestrosti ter pridelavi zdrave hrane. Zagotavljalo naj bi varovanje okolja, kulturne pokrajine pa tudi njeno poseljenost. Pri tem gre predvsem za usmerjanje v ekološko kmetijstvo, katerega značilnost so optimalna pridelava, ki je skladna z naravnim potencialom in izločitev mineralnih gnojil ter pesticidov. Ekološka pridelava hrane tudi najbolj ustreza mozaičnemu pokrajinsko občutljivemu in zemljiško razdrobljenemu vzorcu slovenskih pokrajin.

Lampičeva (2005) ugotavlja, da je uvajanje ekološkega kmetovanja najbolj priporočljivo in okoljsko upravičeno na območjih, kjer je okolje najbolj občutljivo (vodni viri) oziroma tam, kjer so pritiski kmetijske dejavnosti intenzivni ter dolgotrajni in so že sprožili negativne pokrajinske učinke. Ekološko kmetijstvo ima z vidika kmetijske politike v Sloveniji poudarjeno okoljsko in prek okoljskih plačil tudi socialno komponento. Praksa je pokazala, da je smiselno ekološko kmetijstvo kombinirati še z drugimi dopolnilnimi dejavnostmi na kmetiji, npr. predelavo pridelkov, turizmom ipd. Število ekoloških kmetij in delež ekološko obdelanih kmetijskih zemljišč iz leta v leto narašča. Za okoljske razmere v Sloveniji pa bi bila 
pomembnejša njihova ustreznejša prostorska razširjenost. Od več kot 20000 ha ekoloških zemljišč, je $91 \%$ travnikov in komaj $7 \%$ njiv ter $2 \%$ trajnih nasadov, kar nakazuje njihovo usmerjenost, kjer prevladujejo živinorejske in mešane kmetije (Lampič, 2005).

Zakonitost, katere ime je preneseno iz azijske samoobrambne veščine jui jits govori o tem, da se naravni ekosistemi in njihove sestavine obnašajo tako, da moč svojega nasprotnika izkoristijo za svoje delovanje namesto, da bi se mu zoperstavili in s tem po nepotrebnem trošili energijo. S številnimi energetskimi pretvorbami in ob naravni raznovrstnosti se, kljub motnjam, lahko vzpostavi dinamično ravnovesje.

V preteklosti so naši predniki dokazali, da so ob tesnem sožitju z naravo in poznavanju njenih zakonitosti, znali svoje delovanje in posege v prostor uskladiti tudi s tem načelom. Dober primer so npr. samotne kmetije na strmih pobočjih Mežiške doline. Običajno so imeli travnike nad hlevom, da so z manj napora spravili hrano za živino navzdol do hleva, od tod pa so ponovno lažje prenesli gnojilo na njive, ki so bile pod kmetijami. Tako s z manj energije "premagovali nasprotnika - strm relief«.

Drozg (1995) je pri svojem proučevanju morfologije vaških naselij v Sloveniji našel veliko skladnost med tradicionalnim načinom gradnje in naravnogeografskimi značilnostmi posameznih slovenskih pokrajin oziroma domiselne načine premagovanja »naravnih neugodnosti« kot so veter, temperature, relief . Še bolj pa je to načelo opazno pri obmorskih naseljih, kjer ozke ulice in gradbeni material omogočajo zadrževanje hladnejšega zraka v poletnih mesecih in varujejo hiše pozimi pred vdorom hladnih vetrov. Hiše izkoriščajo še temperaturne razlike v posameznih delih zgradbe za gibanje zraka in jih na tak način tudi prezračujejo.

Pri sodobnih graditeljih pa je veliko bolj izražena želja po kljubovanju in upiranju naravnim pogojem. Naselja gradimo v območjih, kjer je gradnja hiš enostavnejša - npr. na poplavnih ravnicah, cenejša in lokacija bolj atraktivna - na strmem reliefu, ali pa so hiše z večjimi okni ali vhodi orientirane proti najbližji poti, čeprav je to smer, od koder najpogosteje pihajo hladni vetrovi. Ko se ob poplavah ali plazovih pokaže neustreznost teh lokacij, govorimo o »naravnih nesrečah«, za vzdrževanje bivalne toplote v hiši pa porabimo veliko več energije kot bi bilo potrebno, če bi bile hiše obrnjene tako, da bi se pred vdorom mrzlega zraka zaščitile z zaprto (brez oken in odprtin) stranjo.

Naravni ekosistemi ustvarjajo proizvode, ki omogočajo njihovo večkratno uporabo. Noben njihov proizvod nima samo enkratne uporabe in ne ustvarja ničesar, kar ni uporabno tudi drugemu. S tam se zmanjša poraba energije in snovi, večja je povezanost med posameznimi sestavinami sistema in na koncu, je še manj odpadka ali pa ga sploh ni.

Zahtevam po zmanjšanju porabe urbanega prostora (npr. gradnja podzemnih garaž) in zmanjšanju rabe energije (kombinacija ogrevanja objektov in proizvodnje energije) bi lahko našli razlago v načelu ,večkratne uporabe«. Neskladen z njim pa je podatek, da v Sloveniji porabimo npr. 4,5 krat več prostora za vsakega prebivalca kot npr. na Danskem ali Nizozemskem, ker se potratno in neracionalno uporabljajo zemljišča za gradnjo hiš, podjetij, trgovskih objektov, zato je tudi v neposredni bližini mestnih naselij $15-20 \%$ površin neustrezno izrabljenih (Dekleva, 1998 v Plut, 2002). Pogačnik (1999) sklepa, da bi ob večji gostoti poselitve, lahko na enaki površini stanovanjskih območij živela tretjina več prebivalcev. 
Za Slovenijo značilen primer upoštevanja zakonitosti večkratnosti je še uporaba lesne biomase tudi kot sonaravnega obnovljivega vira energije. Poraba končne energije se v zadnjih petih letih povečuje za povprečno $1 \%$ letno. Samo $47,9 \%$ porabljene primarne energije v letu 2005 pa je izhajalo iz domačih virov, kar govori o naši veliki energetski odvisnosti. Obnovljivi viri energije so zato strateško pomembni, njihov delež znaša danes okoli $9 \%$, kjer lesna biomasa predstavlja 3,6\% (Kovač, 2006).

Če bo hotela Slovenija izpolnjevati obveznosti iz Kyotskega protokola ter slediti energetski deklaraciji, ki jo je skupaj z državami EU predlagala na svetovnem vrhu o trajnostnem razvoju v Johannesburgu (2002), bo morala v prihodnjih letih povečati uporabo obnovljivih virov energije. Cilj je, do leta 2010 povečati delež obnovljivih virov energije v primarni energetski bilanci na $12 \%$, lesne biomase pa na $6 \%$. Slednja bi lahko pomembno nadomestila fosilna goriva pri ogrevanju objektov, predvsem $\mathrm{z}$ gradnjo sistemov za daljinsko ogrevanje. Prednost uporabe lesne biomase je v tem, da se zmanjšajo emisije $\mathrm{CO}_{2}, \mathrm{SO}_{2}$, izboljša se skrb za gozdove, odstrani se tveganje, ki ga prinaša prevoz in skladiščenje tekočih in plinastih goriv, zmanjšala bi se energetske odvisnost od uvoza itd.

Načrti za povečano uporabo lesne biomase imajo realno osnovo $v$ nenehnem povečevanju deleža gozda. Strokovnjaki govorijo že o $63 \%$ pokritosti z gozdom in o tem, da močno naraščajo tudi povprečne lesne zaloge. Dejanski obseg poseka pa že vrsto let zaostaja za dovoljenim in priporočljivim, kar priča tudi o zanemarjanju proizvodne funkcije gozdov.

Naravni ekosistem oziroma vse njegove sestavine ustvarjajo z energetskimi pretvorbami le snovi, ki so življenjsko pomembne za druge ali pa se na koncu razgradijo. Označuje jih snovno-energetski krogotok, odpadka ni, t. im. odpadek se vedno reciklira in je uporaben drugim. Učinkovitost reciklaže se povečuje z raznovrstnostjo ekosistema, ker je več »uporabnikov« $\mathrm{z}$ različnimi funkcijami in potrebami po biomasi.

$\mathrm{V}$ človekovem delovanju pa se večina neobnovljivih naravnih virov uporabi kot surovina za proizvode, ki se na koncu zavržejo v obliki odpadka. Zato naraščajo količine odpadkov. Sonaravno ravnanje z odpadki bi pomenilo premik od linearnega načina razmišljanja k cikličnem, zato bi se morali odpadki kot surovine vrniti na začetek snovnega toka - reciklirati. S stališča snovnih in energetskih bilanc ima preprečevanje, vnovična uporaba, predelava, reciklaža neprimerno boljši snovni izkoristek (Keuc, 2005). V svetu se danes pojavljata dve strategiji ravnanja $\mathrm{z}$ odpadki. T.im. integralno gospodarjenje predvideva le okoli $40 \%$ reciklaže in s tem dopušča v veliki meri tudi ohranjanja dosedanjih vzorcev odnosa do odpadkov. Boljše, a v praksi težko dosegljivo pa je priporočilo »zero waste«, po katerem se spremlja cel življenjski cikel odpadka, ki vključuje reciklažo po načelu: dober odpadek je tisti, ki ga je mogoče reciklirati.

Slovenija proizvede po podatkih za leto 2004 okoli 400kg komunalnih gospodinjskih odpadkov na prebivalca (ARSO, 2007), kar je za dobrih 100kg pod povprečjem EU. Povečuje se tudi delež gospodinjstev, ki so vključena v sistem rednega zbiranja in dovoza komunalnih odpadkov. Od leta 1995 , ko je bil ta delež $76 \%$, se je do leta 2001 povečal na $94 \%$. Za ravnanje z odpadki so zadolžene lokalne gospodarske javne službe. V letu 2004 jih je bilo registriranih 56 in vsa so že zagotavljala ločeno zbiranje odpadkov, leto pred tem jih je $86 \%$ ločeno zbiralo odpadke (ARSO, 2005). Značilno je, da so sistematično z ločenim zbiranjem odpadkov začeli najprej $v$ manjših naseljih, šele $v$ zadnjih letih so se jim priključila večja mesta, npr. Ljubljana. V strnjenih naseljih so kontejnerji za ločeno zbiranje komunalnih 
odpadkov v povprečju na vsakih 500 prebivalcev. Zahteva po ločenem zbiranju odpadkov ni sankcionirana in je bolj odraz ekološke ozaveščenosti posameznika. O njeni relativni neučinkovitosti govori tudi podatek, da je na odlagališčih komunalnih odpadkov kar $83 \%$ mešanih odpadkov, kar je daleč za povprečjem EU, kjer je tovrstnih odpadkov okoli polovica (ARSO, 2005).

Med vsemi fazami gospodarjenja s komunalnimi odpadki je z vidika sonaravnosti najslabše poskrbljeno na področju odstranjevanja oziroma predelave odpadkov. Cilj, ki smo si ga zadali v strategiji varstva okolja in od katerega še vedno precej odstopamo je, da bi bilo potrebno pred odstranjevanjem usmeriti v različne postopke predelave vsaj $65 \%$ komunalnih odpadkov. Odlaganje odpadkov je še vedno najbolj razširjen način njihovega odstranjevanja. Leta 2004 se je na odlagališčih odložilo kar 82\% komunalnih odpadkov, v druge predelave ali vnovično uporabo pa je bilo vključeno $6 \%$ odpadkov, v sežig nadaljnjih $8 \%$ odpadkov, reciklažo sekundarnih surovin pa 1,4\% in kompostiranje 1,4\% komunalnih odpadkov (ARSO, 2005).

V naravnih ekosistemih ima simbioza različne oblike, prinaša pa korist vsem, ker se zmanjša poraba energije in snovi, skrajšajo se poti, uporabi se manj prostora, poveča se tudi notranja odvisnost. $Z$ raznovrstnostjo sistema se povečuje raznovrstnost oblik in možnosti sožitja - simbioze.

Z upoštevanjem te zakonitosti bi v prostorskem, predvsem pa v urbanističnem načrtovanju moral postati imperativ optimalno približevanje sfer bivanja, dela, izobraževanja, oskrbe itd. Obstoječi in prevladujoči koncepti oddaljevanja omenjenih področij človekovega delovanja in ustvarjanja funkcijsko homogenih con (npr. nakupovalnih središč na obrobju mesta, industrijskih con daleč od kraja bivanja, preseljevanje v širša suburbana in podeželska naselja zaradi visokih cen stanovanj v mestih itd) že sami po sebi vodijo v nesonaravnost, v povečano porabo energije, prostora, podaljševanje prometnih poti, onesnaževanje okolja in posledično v zmanjševanje kvalitete življenja. Kakšna je kvaliteta življenja velikega števila Francozov, ki dnevno porabijo več kot 4 ure za vožnjo na delo v Pariz in nazaj v domove, ki so jih, zaradi dragega življenja v Parizu, preselili na podeželje ali manjša obrobna mesta?

Tudi za Slovenijo je značilno, da prihaja do koncentracije delovnih mest v večjih zaposlitvenih središčih, kar močno povečuje dnevno migracijo predvsem z osebnimi vozili. $58 \%$ zaposlenih se vsakodnevno vozi na delo v drugo naselje, samo v Ljubljano prihaja $15 \%$ vseh delovnih migrantov Slovenije, med njimi vsaj 35000 prebivalcev ljubljanske urbane regije, ki potujejo z osebnimi avtomobili. Glede na nizko povprečno zasedenost osebnih vozil v Sloveniji (1,28 ljudi na osebno vozilo), pomeni, da se samo iz širše urbane regije dnevno pripelje v mesto okoli 25.000 vozil (Gabrovec s sodelavci, 2000). Zaradi dnevne migracije (delo, šola, nakupi, otroško varstvo) iz obrobja mesta in znotraj mesta, je v Ljubljani na cestah dnevno več kot 150000 vozil (Plut, 2007). Celodnevne prometne obremenitve v zadnjih letih naraščajo z neverjetno naglico. Zaradi slabe organiziranosti in uporabe javnega prevoza je mesto vedno bolj zasičeno s prometom. Poleg tega pa postaja prometno onesnaževanja okolja, predvsem ozračja, zelo pereč, če že ne kar prevladujoč okoljevarstveni problem prestolnice. Prekomerna hrupno obremenjevanje pa zmanjšuje kvaliteto bivalnega okolja posameznim mestnim območjem. Iskanje rešitev zgolj v posodabljanju javnih prevoznih sredstev, ki so sicer okoljsko manj obremenjujoča, je le delna in kratkotrajna rešitev, ki pa ne 
bo pomembneje vplivala na kvaliteto življenja in preživljanja prostega časa. Še vedno bodo dnevni migranti preživeli velik del dneva na poti. Dolgoročnejše in sonaravne rešitve gre iskati v ustvarjanju mešanih urbanih površin, s približevanjem delovnih mest, vrtcev, šol, rekreacijskih in oskrbnih objektov stanovanjskim območjem. S simbiozo teh dejavnosti bi se pomembneje zmanjšala poraba energije, zasedenost prometnih poti, izguba časa, skratka zmanjšalo bi se obremenjevanje okolja in izboljšala kvaliteta bivanja.

Zanimiv ekosistemski mehanizem ravnovesja, ki ga je nemški ekolog Vester (1991) prevzel iz biokibernetike, govori o približevanju k sonaravnosti s posnemanjem naravnega vzorca, s katerim priporoča, da naj človek, pri svojem delovanju in tudi zmanjševanju obremenjevanja okolja ter njegovi sanaciji, čim bolj kopira delovanje narave in posnema naravne oblike.

Naši predniki so pri oblikovanju svojih bivališč izkustveno znali dobro upoštevati to načelo. Zanimive in še danes zelo privlačne so vasi, kjer so z gradnjo hiš sledili reliefnemu naklonu, kjer so velika okna obračali na prisojo (kot rastline svoje cvetove in liste proti soncu), manjša pa v osojo ali slemenska naselja, ki z razporeditvijo hiš in gospodarskih poslopij povsem sledijo širini slemena. Tudi $v$ mestih so veliko bolj zanimive razgibane fasade kot enolične zgradbe, ki v ničemer ne odražajo specifičnosti okolja.

Med uspešnejše sonaravne oblike, ki sledijo naravnemu vzoru, spadajo ekoremediacije, $\mathrm{s}$ katerimi se poizkuša odpraviti posledice človekovih posegov v vodne ekosisteme ali mokrišča. Če ti delujejo po naravnih zakonitostih, imajo namreč precej povečane nevtralizacijske sposobnosti. Še posebej velja to za mokrišča, ki zaradi svoje izjemne raznovrstnosti, lahko opravljajo številne samočistilne in regeneracijske naloge tudi za človekove potrebe. Ekoremediacija vključuje procese, ki potekajo $v$ naravi in s katerimi se dosegajo visoki učinki pri zaščiti vodnih virov brez velikih stroškov. Z njimi se skuša ekosistemu vrniti del izgubljenega potenciala.

Samočistilne sposobnosti narave se posnema tudi pri delovanju rastlinskih čistilnih naprav s čiščenjem z močvirskimi rastlinami. Za njihovo delovanje nista potrebna energija ne strojna oprema, so pa tudi pokrajinsko privlačni objekti. Omogočajo najbolj sonaravno čiščenja komunalnih odplak, izcednih (iz deponij) in tehnoloških voda (npr. iz farm). Učinkovito zmanjšujejo onesnaženost do $90 \%$, namenjene pa so zmanjševanju dušikovih in fosforjevih spojin, težkih kovin in drugih strupenih snovi. V Sloveniji so jih začeli graditi po letu 1989, predvsem za čiščenje odpadnih voda iz manjših naselij, turističnih objektov, stanovanjskih kompleksov in komunalnih deponij. Večina med delujočimi čistilnimi napravami ima zmožnost čiščenja do nekaj sto PE (Medmrežje 1)

Najučinkovitejši mehanizem, ki vzdržuje naravni ekosistem v ravnovesju pa je regulacijska zanka ali negativni povratni lok. »Ekosistemski krmar« (kybernetes), ki je njegov sestavni del, namreč preprečuje preseganje nosilnih sposobnosti sistema in skrbi za ohranjanje njegove stabilnosti. Če bi ekosistem ali njegove sestavine prehitro ali preveč naraščale, bi s tem presegle njegov potencial in posledično bi lahko prišlo do njegovega kolapsa ali katastrofe. V naravnem ekosistemu bo regulacijska zanka to prekomerno rast zaustavila in ga ponovno uravnala $\mathrm{v}$ dinamično ravnovesja. Rast in razvoj sta prav tako sestavna dela delovanja naravnih ekosistemov, vendar mora nad njima vedno dominirati in ju nadzorovati regulacijska zanka, da vzpostavi ravnovesje. 
Ko prenašamo zakonitost regulacijske zanke v delovanje antropogeno preoblikovanih ekosistemov, se vedno pojavi vprašanje: kje so meje rasti, kdaj bo razvoj že ogrozil nosilne sposobnosti ekosistema? Teh mejnih vrednosti zagotovo ne moremo določiti z matematično natančnostjo. Računati moramo še na že omenjeno nepredvidljivost, ki tudi dobro načrtovane posege lahko spremeni v okolju škodljive ali v prevelika bremena za posamezne ekosisteme. Nepredvidljivost in morebitne negativne okoljske učinke posameznih posegov lahko precej zmanjšamo z dobrim strokovnim ovrednotenjem oziroma kvantifikacijo okolja in vseh njegovih sestavin in predvsem $\mathrm{z}$ oceno njegovih samočistilnih ter regeneracijskih sposobnosti.

Ali so ob načrtih vsakoletnega povečevanja obsega in intenzivnosti namakanja kmetijskih površin na območju vzhodnoevropskih step pričakovali, da bodo presegli kritično mejo in bodo z zasoljevanjem sprožili popolno degradacijo nekdaj rodovitnih polj? Ali so načrtovalci razvoja nekaterih turističnih območij v Sredozemlju (npr. Lloret de Mar ali južne obale kanarskega otoka Tenerife) razumeli, da bodo z nenehnim povečevanjem gostote turističnih objektov presegli kritično točko in nosilno sposobnost okolja, ki se kaže v pomanjkanju neoporečne pitne vode, onesnaženju morja, neobvladljivih količinah odpadkov in splošni neprivlačnosti hotelskih »nebotičnikov«. Ker ni bila pravočasno sprožena regulacijska zanka, so turistični kraji postali nezanimivi za zahtevnejše turiste in živijo na račun kvantitete, ki pa ponovno vodi v še večje okoljsko obremenjevanje.

Do degradacije okolja, izgubljanja biotske pestrosti, segrevanja ozračja in drugih negativnih okoljskih učinkov je prišlo prav zaradi tega, ker smo računali na neomejene regeneracijske sposobnosti narave ali pa smo zanemarili opozorila, da so naši posegi in vnosi (rast) že dosegli ali presegli opozorilno ali kritično točko, ko bi morala nastopiti regulacijska zanka (zaustavitev, zmanjšanje posegov), da bi se ponovno vzpostavilo ravnovesje. S tem pa se ponovno vračamo na izhodiščno vprašanje: kaj je sonaravnost oziroma in zakaj je načrtovanje sonaravnega razvoja $\mathrm{v}$ bistvo nenehno iskanje in vzdrževanje dinamičnega ekosistemskega ravnovesja.

\section{POVZETEK}

Koncept sonaravnega razvoja temelji na zahtevi po vzdrževanju eksosistemske stabilnosti oziroma dinamičnega ravnovesja, ki dopušča spremembe, človekove vplive in razvoj, pod pogojem, da ta ne presega nosilnosti okolja in, da razvoj upošteva osnovne ekosistemske mehanizme ravnovesja.

Sonaravni razvoj izhaja iz sposobnosti ekosistemov, da prenesejo kvalitativne spremembe, ki dolgoročno prinašajo socialni, gospodarski, tehnološki razvoj. Pri teh spremembah lahko kratkoročno posamezni deli sistema sicer zanihajo v nesonaravnost, a dolgoročno se morajo vedno uravnotežiti z naravnim potencialom oziroma nosilnostjo okolja.

Sonaravni razvoj nekega območja torej izhaja iz njegovega potenciala, ki omogoča dolgoročno ravnotežje, kljub občasnim nihanjem.

Za razlago sonaravnosti lahko uporabimo tudi nekatere ekosistemske mehanizme ravnovesja, ki imajo vzglede v delovanju naravnih ekosistemov. Skozi evolucijo so ti namreč 
dokazali, da imajo neke t.i. notranje regulatorje, ki jim zagotavljajo dolgoročno vzdrževanje dinamičnega ravnovesja, ki pa je nezdružljivo s stalno rastjo. Rast je sicer gonilo razvoja, vedno pa ga mora nadzorovati negativna regulacijska zanka, ki ga ponovno uravnoteži z naravnim potencialom Odvisnost od rasti je namreč nevarna in je ekosistemski nesmisel. Poleg tega ima v naravnem ekosistemu vsaka njegova sestavina neko funkcijo, neodvisno od proizvoda, kar jim mogoča veliko prilagodljivost in preživetje tudi ob spremembi. $\mathrm{Ob}$ upoštevanju delovanja naravnih ekosistemov bi morali pri sonaravnem razvoju težiti $\mathrm{k}$ občutnem zmanjšanju odpadkov, ki se ne reciklirajo, prav tako pa bi s simbiozo različnih sfer človekovega delovanja ali z večkratno uporabo zmanjšali porabo energije, prostora, snovi in posledično onesnaževanje okolja ter izboljšali kvaliteto življenja. Če bi naselja ali prometne poti gradili tako, da bi se čim manj »upirali« naravnim razmeram, bi lahko zmanjšali tudi negativne posledice t.i. naravnih nesreč, s posnemanjem naravnih vzorcev pa bi z majhnimi finančnimi in energetskimi vnosi zagotovili kvalitetnejše bivanje pa tudi sanacijo preteklih ekoloških bremen.

\section{Literatura in viri}

Agencija RS za okolje (ARSO), 2007. Kazalci okolja 2005, Ljubljana.

Agencija RS za okolje (ARSO), 2005. Analiza podatkov o ravnanju s komunalnimi odpadki v RS iz letnih poročil za leto 2004, Ljubljana.

Dekleva, J., 1998. Pregled instrumentov prostorske regulacije, Ljubljana, str. 43.

Drozg, V., 1995. Morfologija vaških naselij v Sloveniji, Geographica Slovenica, Ljubljana, str. $40-45$.

Gabrovec. M., Pavlin, B., Sluga, G., 2000. Dostopnost do javnega potniškega prometa, Ljubljana- geografija mesta, Založba ZRC, Ljubljana, str.252.

Keuc, A., 2005. Preprečevanje in zmanjševanje odpadkov v Sloveniji, Umanotera, Ljubljana, str. 160 .

Kovač, Š., 2006. Les-od gozda do peči, Global Environmental Facility, MOP, Ljubljana, str. 13.

Lah, A., 2004. Bistvo sonaravne razvojne strategije, Sonaravno uravnoteženi razvoj Slovenije, Svet za varstvo okolja Republike Slovenije, Ljubljana, str.12.

Lampič, B., 2005. Kmetijstvo kot priložnost sonaravnega razvoja podeželja v Sloveniji, Dela 23-Geografski pogledi na regionalni razvoj, Ljubljana,.str. 167-221.

Medmrežje 1: http//www.limnos.si/reference.html; 25.8..2007

Ministrstvo za okolje in prostor (MOP), 2005: Resolucija o nacionalnem programu varstva okolja, Ljubljana.

Nijkmp, P., Perrels, A., 1994. Urban Sustainabilty as a New Paradigm, Sustainable Cities in Europa, Earhtscan Publication, London, str. 4.

Park, C., 1997. The Environment, Principles and Applications, Rotledge, New York, str.48. Vester, F., 1991. Kriza prenaseljenih območij. O razvijanju ekosistemskega mišljenja, DZS, Ljubljana, str. 59-77.

Plut, D., 2002, Okoljevarstveni vidiki prostorskega razvoja Slovenije, Razprave Filozofske fakultete Ljubljana, str.17. 
Plut, D., 2007. Okoljska analiza in presoja prostorskega razvoja Mestne občine Ljubljana v obdobju 1990 - 2015, MOL, str. 17.

Pogačnik, A., 1999. Urbanistično planiranje, Univerzitetni učbenik, FGG, Ljubljana, str. 252.

WCED, 1987. Our Common Future, Oxford University Press, Oxford, str. 46

\title{
THE IMPORTANCE OF MAINTAINING THE DYNAMIC EQUILIBRIUM FOR SUSTAINABLE DEVELOPMENT
}

\begin{abstract}
Summary
The concept of sustainable development is based on the necessity of maintaining the ecosystem stability, or the dynamic equilibrium, which allows changes, human impacts or development, provided that these do not exceed the environmental carrying capacity, and, that they do take account of the basic ecosystem balancing mechanisms.

The essence of sustainable development is that ecosystems are capable of sustaining qualitative changes which, in the long run, result in social, economic, technological, etc., developments. Through these changes individual parts of the system can, in a short-term perspective, move away to un-sustainability, but in a long-term perspective, the balance between them and the natural potential or the environmental carrying capacity always has to be restored.

Accordingly, sustainability of the environment proceeds from its potential which enables the long-term balance despite its periodical oscillations. To account for sustainability, some ecosystem balancing mechanisms can be applied which follow the examples of natural ecosystems. The latter have proved throughout the evolution that inherent to them are certain so-called inner regulators that, in the long run, ensure the maintenance of the dynamic balance, which, however, is incompatible with constant growth. It is true that growth is the driving power of development, yet all the time it should be controlled by the negative regulation loop which restores the balance between it and the natural potential. As a matter of fact, the dependence on growth is dangerous and it is an ecosystem absurdity. Moreover, every constituent in the natural ecosystem has a certain function, independent from the product, which gives them great flexibility and enables their survival even in the case of change.

The paper presents the importance of the selected ecosystem balancing mechanisms that are typical of the functioning of natural ecosystems and could also serve as examples for human interventions, through which the paradigm of sustainability, or the long-term maintaining of the dynamic balance, could be approached.
\end{abstract}

